\title{
Synthesis of Tetrahydrofurans from Aldehydes and Cyclopropanes
}<smiles>COC(=O)C1(C(C)=O)CC1</smiles><smiles>[R]C=O</smiles>

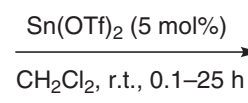<smiles>COC(=O)C1(C(=O)OC)C[C@H]1c1ccccc1</smiles>

4<smiles>[2H]C=O</smiles>

5

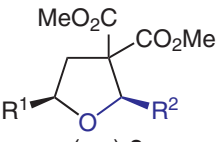

(rac) -3 $60-98 \%$ d.r. $1.6: 1$ to $>100: 1$ 24 examples

$\mathrm{MeO}_{2} \mathrm{C}$

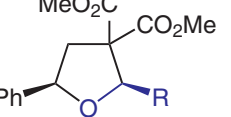

6 54-100\% $\mathrm{dr}=1.6: 1$ to $>100: 1$ er $=67: 33$ to $99.5: 0.5$

10 examples
$\mathrm{R}^{1}=\mathrm{Ph}, 4-\mathrm{MeC}_{6} \mathrm{H}_{4}, 4-\mathrm{MeOC}_{6} \mathrm{H}_{4}, 4-\mathrm{BrC}_{6} \mathrm{H}_{4}$ 4- $\mathrm{AcOC}_{6} \mathrm{H}_{4}, 4-\mathrm{MeO}_{2} \mathrm{CC}_{6} \mathrm{H}_{4}$, 2-thienyl, (E) $-\mathrm{CH}=\mathrm{CHPh}$

$\mathrm{R}^{2}=\mathrm{Et}, i-\mathrm{Pr}, \mathrm{Ph}, 4-\mathrm{MeC}_{6} \mathrm{H}_{4}, 4-\mathrm{MeOC}_{6} \mathrm{H}_{4}$ 4- $-\mathrm{ClC}_{6} \mathrm{H}_{4}, 4-\mathrm{BrC}_{6} \mathrm{H}_{4}, 4-\mathrm{O}_{2} \mathrm{NC}_{6} \mathrm{H}_{4}$, 4- $\mathrm{AcOC}_{6} \mathrm{H}_{4}, 4-\mathrm{MeO}_{2} \mathrm{CC}_{6} \mathrm{H}_{4}$, 2-furyl 2-thienyl, $(E)-\mathrm{CH}=\mathrm{CHPh}, \mathrm{C} \equiv \mathrm{CPh}$

$\mathrm{R}=\mathrm{Et}, i-\mathrm{Pr}, \mathrm{Ph}, 4-\mathrm{MeOC}_{6} \mathrm{H}_{4}, 4-\mathrm{ClC}_{6} \mathrm{H}_{4}$ 4- $\mathrm{O}_{2} \mathrm{NC}_{6} \mathrm{H}_{4}$, 2-furyl, 2-thienyl, $(E)-\mathrm{CH}=\mathrm{CHPh}, \mathrm{C} \equiv \mathrm{CPh}$

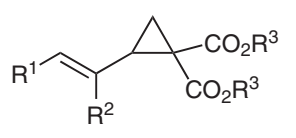

7

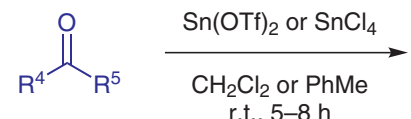

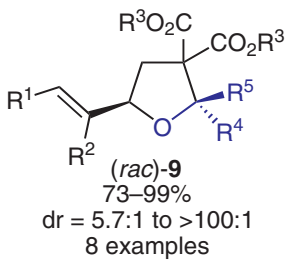

$\mathrm{R}^{1}=\mathrm{H}, \mathrm{Me}$

$\mathrm{R}^{2}=\mathrm{H}, \mathrm{Me}$ $\mathrm{R}^{3}=\mathrm{Me}, \mathrm{Bn}$ $\mathrm{R}^{4}=\mathrm{H}, \mathrm{Me}$ $\mathrm{R}^{5}=i-\mathrm{Pr}, \mathrm{Ph}$
Significance: The synthesis of cis-2,5-disubstituted tetrahydrofurans via Lewis acid catalyzed [3+2] cycloaddition of cyclopropanes with aldehydes is described. Treatment of racemic 2-arylcyclopropanes 1 with a range of aldehydes 2 using $\mathrm{Sn}(\mathrm{OTf})_{2}$ as catalyst led to cis-substituted tetrahydrofurans $\mathbf{3}$ in good to excellent yield, with excellent diastereoselectivity in most cases.

Extensive screening of Lewis acids was carried out to obtain the optimized conditions. A broad range of functional groups are tolerated and optically active tetrahydrofurans $\mathbf{6}$ may be obtained from enantiopure cyclopropane $\mathbf{4}$ without the need for a chiral ligand control. Inversion of the stereocenter was observed during this process. The scope of the reaction was extended to accommodate the reaction of vinylcyclopropanes 7 with both aldehydes and ketones $\mathbf{8}$ to give tetrahydrofurans $\mathbf{9}$, also in high yield and diastereoselectivity.

sYNFACTS Contributors: Victor Snieckus, Timothy Hurst Synfacts 2008, 9, 0913-0913 Published online: 22.08.2008 DoI: 10.1055/s-2008-1078612; Reg-No.: V09408SF
Comment: The tetrahydrofuran structure is found in a variety of biologically active compounds. Cycloadditions provide a particularly attractive route to the tetrahydrofuran core due to high convergence and atom economy. The current method represents an efficient one-pot procedure. Further modification of the products by decarboxylation and ozonolysis was also demonstrated. The starting cyclopropanes were easily prepared from benzaldehydes and diethyl malonate via Knoevenagel condensation followed by treatment with dimethyloxosulfonium methylide. Evidence for a mechanism involving an unusual stereospecific ion pair mechanism where the aldehyde acts as a nucleophile with malonate as the nucleofuge was obtained. 